\title{
HUBUNGAN KELIMPAHAN LARVA IKAN DENGAN KERAPATAN MANGROVE YANG BERBEDA DI KAWASAN DELTA WULAN, KABUPATEN DEMAK
}

\author{
The Relationship between Larval Fish Abundance with Density of Mangrove in Delta Wulan, Demak District
}

\author{
Dimas Rahmat Ramadhian, Niniek Widyorini *), Anhar Solichin
}

Program Studi Manajemen Sumberdaya Perairan, Departemen Sumberdaya Akuatik Fakultas Perikanan dan Ilmu Kelautan, Universitas Diponegoro Jl. Prof. Soedarto, SH, Tembalang, Semarang, Jawa Tengah - 50275, Telp/Fax +6224 7474698 Email : dimasrramadhian@gmail.com

\begin{abstract}
ABSTRAK
Larva adalah biota perairan yang bersifat planktonik dan termasuk ke dalam jenis meroplankton. Stadia larva merupakan fase awal daur kehidupan bagi ikan. Perairan delta merupakan perairan yang subur karena di kawasan tersebut terjadi penumpukan nutrien maupun bahan organik yang berasal baik dari daratan maupun lautan yang terjebak atau terendapkan. Delta-delta yang ada di daerah tropis hampir seluruhnya ditumbuhi oleh mangrove. Hal tersebut seperti yang terlihat di beberapa delta besar di daerah tropis yang salah satunya terdapat di Delta Wulan, Demak. Berbagai penelitian menunjukkan bahwa ekosistem mangrove merupakan perairan yang subur dan berfungsi sebagai daerah asuhan dari berbagai jenis larva ikan. Kondisi kerapatan mangrove yang berbeda dapat pula mempengaruhi kelimpahan dan komposisi larva ikan. Penelitian ini bertujuan untuk mengetahui kelimpahan dan komposisi larva ikan pada kerapatan mangrove yang berbeda dan mengetahui hubungan antara kelimpahan larva ikan dengan kerapatan mangrove yang berbeda. Metode penelitian yang digunakan adalah metode studi kasus. Hasil yang diperoleh adalah pada stasiun I tingkat kerapatan mangrove padat (3200 Pohon/Ha) nilai kelimpahan larva ikan sebesar 290 individu/250 $\mathrm{m}^{3}$ terdiri dari 16 famili. Stasiun II tingkat kerapatan mangrove sedang (1500 Pohon/Ha) nilai kelimpahan larva ikan sebesar 133 individu/250 $\mathrm{m}^{3}$ terdiri dari 11 famili, dan stasiun III tingkat kerapatan mangrove jarang (600 Pohon/Ha) nilai kelimpahan larva ikan sebesar 79 individu/250 $\mathrm{m}^{3}$ terdiri dari 11 famili. Nilai koefisien korelasi antara kelimpahan larva ikan dengan kerapatan mangrove yaitu sebesar $r=0,980$. Berdasarkan hal tersebut dapat disimpulkan bahwa terdapat hubungan positif antara kelimpahan larva ikan dengan kerapatan mangrove.
\end{abstract}

Kata kunci: kelimpahan; larva ikan; kerapatan mangrove; Delta Wulan

\section{ABSTRACT}

Larvae is one of aquatic organism with behavior as same as the plankton and belongs to the type of meroplankton. The first life form of fish is known as larvae. Delta as one of aquatic environment is a rich area with high productivity due to the accumulation both of nutrient and organic matter derived from the headwaters and sea. Most of the deltas in tropical area that occupied with the tree of mangroves. Such as in several large delta in the tropics that one of them include Delta Wulan, Demak. Several study has shown the result that the ecosystem of mangrove is a high flourish area. Many species of larval fish depends on mangroves as the nursery area. The different condition of mangrove density can affect the abundance and composition of larval fish. The purposes of this research are to determine the abundance and composition of larval fish in the different condition on mangrove density and to determine relation between the abundance of larval fish with different condition of mangrove density. This research were used the case study method. The results of this research on three different station are: high density with total of 3200 trees/Ha and total of the abundance of larval fish are 290 Individual/250 $\mathrm{m}^{3}$ consist of 16 families. On station 2, medium density with total of 1500 trees/Ha and total of the abundance of larval fish are 133 Individual/250 $\mathrm{m}^{3}$ consist of 11 families, while on station 3, rare density with total of 600 trees/Ha and total of the abundance of larval fish are 79 Individual/250 $\mathrm{m}^{3}$ consist of 11 families. The correlation value of statistic between the abundance of larval fish with the different condition of mangrove density is shown with total $r$ value of 0,980. Conclusion of this research shows there is a correlation between the abundance of larval fish with the density of mangrove.

Keywords : abundance; larval fish; mangrove density; Delta Wulan

*) Penulis penanggungjawab

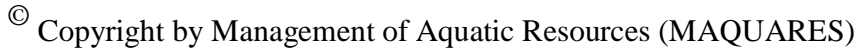




\section{PENDAHULUAN}

Sungai-sungai yang ada di Pulau Jawa membawa sedimen yang sangat besar dan akhirnya terdepositkan di muara sungai dan tepian pantai membentuk daratan intertidal yang disebut delta (Suryono, 2006). Perairan delta merupakan perairan yang subur karena di kawasan tersebut terjadi penumpukan nutrien maupun bahan organik yang berasal baik dari daratan maupun lautan yang terjebak atau terendapkan. Delta-delta yang ada di daerah tropis hampir seluruhnya ditumbuhi oleh mangrove. Hal tersebut seperti yang terlihat di beberapa delta besar di daerah tropis yang salah satunya terdapat di Delta Wulan, Demak.

Stadia larva merupakan fase awal daur kehidupan bagi ikan. Stadia larva ini diawali dari penetasan telur hingga terbentuknya bagian atau organ tubuh seperti ekor dan sirip, meskipun belum terbentuk secara sempurna. Larva adalah biota perairan yang bersifat planktonik dan termasuk ke dalam jenis meroplankton, dimana sebagian siklus hidupnya hidup sebagai plankton dan sebagian lagi berkembang menjadi organisme dewasa. Larva berukuran sangat kecil (mikroskopis), transparan, dan bentuk tubuh masih sulit dibedakan dengan ukuran dewasa. Keberadaan larva ikan di perairan memiliki peranan cukup penting. Kelimpahan dan penyebaran larva ikan dapat menentukan kondisi atau status sumberdaya ikan yang ada pada suatu perairan, hal tersebut dikarenakan larva ikan merupakan fase pertama kehidupan dimana ikan akan berkembang menjadi ikan dewasa. Kondisi lingkungan perairan sangat menentukan keberadaan dan penyebaran organisme di dalamnya. Faktor lingkungan yang dapat mempengaruhi keberadaan dan penyebaran larva yaitu meliputi faktor fisik, kimiawi, dan biologi. Setiap fase larva ikan memiliki karakteristik lingkungan yang berbeda untuk hidup atau tinggal di suatu habitat. Stadia larva merupakan fase atau siklus yang paling kritis karena kehidupannya masih tergantung pada kondisi lingkungan perairan seperti keberadaan predator, ketersediaan makanan, dan fluktuasi suhu. Jika pertumbuhan dan perkembangan larva terganggu dikhawatirkan sumberdaya ikan yang ada di perairan tersebut akan menurun.

Variasi kerapatan di suatu ekosistem mangrove dapat mempengaruhi kelimpahan larva ikan. Hal ini berhubungan dengan daerah pemijahan, tempat berlindung, ketersediaan makanan, kebiasaan makan dan jenis makanan ikan tertentu. Alasan ini yang digunakan peneliti sebagai landasan pentingnya penelitian ini dilakukan. Data yang diperoleh akan digunakan sebagai informasi untuk pengelolaan sumberdaya perikanan di kawasan Delta Wulan, Demak.

\section{MATERI DAN METODE PENELITIAN}

Materi penelitian adalah larva ikan dan mangrove berdasarkan kerapatan yang berbeda, di kawasan Delta Wulan, Kabupaten Demak. Penelitian ini mengamati tentang kelimpahan larva ikan dengan kerapatan mangrove yang berbeda. Selain materi utama dilakukan pengukuran kualitas air meliputi kedalaman, temperatur, kecepatan arus, salinitas, $\mathrm{pH}$, dan oksigen terlarut untuk dijadikan data pendukung.

Metode penelitian yang digunakan adalah metode Studi Kasus, dimana pelaksanaan penelitian hanya mendalami pada kasus tertentu saja. Metode ini menggambarkan secara mendalam suatu masalah yang didapat belum tentu berlaku di daerah lain dengan objek penelitian yang sama (Hadi, 1982 dalam Adi, 2007).

Penentuan lokasi sampling dilakukan dengan melakukan beberapa kali observasi. Observasi ini dilakukan dengan cara mencari vegetasi mangrove dengan tiga kerapatan yang berbeda yaitu kerapatan padat, sedang, dan jarang. Kerapatan mangrove dihitung berdasarkan jumlah pohon mangrove dalam kuadran transek ukuran 10x10 m (Romimohtarto dan Juwana, 2005). Observasi dilakukan dengan acuan Keputusan Menteri Negara Lingkungan Hidup Nomor 201 Tahun 2004 tentang Kriteria Baku dan Pedoman Kerusakan Mangrove. Peta lokasi penelitian tersaji pada Gambar 1.

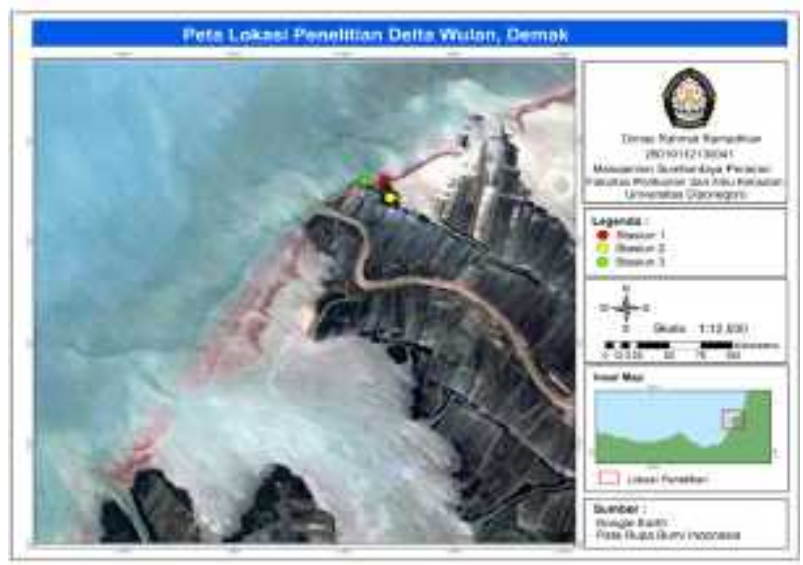

Gambar 1. Peta Lokasi Penelitian

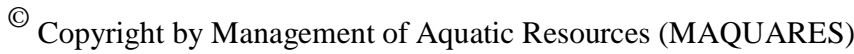


Pada sampling utama dilakukan pengambilan sampel larva ikan dengan metode sistematik sampling yaitu sampel diambil dari populasi pada jarak, interval waktu, ruang, atau urutan yang seragam. Diharapkan dengan menggunakan metode sistematik sampling akan didapat sampel yang mewakili populasi yang diamati (Sudjana,1996). Pengambilan sampel larva ikan dilakukan dengan seine net ukuran 2x1 m, pada masing-masing stasiun. Sampling dilakukan pada pukul 08.00-12.00 WIB.

Penelitian ini dilakukan pada bulan Februari-April 2016 di kawasan Delta Wulan, Kabupaten Demak. Sedangkan kegiatan laboratorium dilakukan di Laboratorium Pengelolaan Sumberdaya Ikan dan Lingkungan, Fakultas Perikanan dan Ilmu Kelautan Universitas Diponegoro, Semarang.

Data larva ikan yang terkumpul dianalisa untuk mengetahui nilai kelimpahan dan kelimpahan relatif. Perhitungan dilakukan dengan rumus sebagai berikut:

1. Kelimpahan (Fadli dan Surahman, 2013)

$$
\mathrm{N}=\frac{2 \mathrm{n}}{\mathrm{Vtat}}
$$

2. Kelimpahan Relatif (Odum, 1993)

$$
\mathrm{KR}=\frac{\text { ai }}{\mathrm{L}^{\mathrm{m}}} \times 100 \%
$$

Keterangan :

$\mathrm{N}$ : Kelimpahan larva ikan (ind $/ \mathrm{m}^{3}$ )

$\sum \mathrm{n}$ : Jumlah larva ikan (ind)

$\mathrm{V}_{\mathrm{tsr}}$ : Volume air tersaring $\left(\mathrm{m}^{3}\right)$

KR : Kelimpahan relatif (\%)

ni : Jumlah individu dari famili ke-i

\section{HASIL DAN PEMBAHASAN}

\section{A. HASIL}

Penelitian dilakukan di kawasan Delta Wulan wilayah Desa Menco, Kecamatan Wedung, Kabupaten Demak. Ada tiga jenis mangrove yang mendominasi di lokasi penelitian ini yaitu Rhizopora apiculata, Rhizopora mucronata, dan Avicennia marina. Lokasi penelitian ini kemudian dibagi berdasarkan kerapatan mangrove menjadi tiga stasiun penelitian, yaitu ekosistem mangrove di stasiun I dengan kerapatan padat (3200 pohon/Ha), ekosistem mangrove di stasiun II dengan kerapatan sedang (1500 pohon/Ha), dan ekosistem mangrove di stasiun III kerapatan jarang (600 pohon/Ha). Stasiun I pada koordinat 06\%33'29.5" LS dan $110^{\circ} 33^{\prime} 21.9^{\prime \prime}$ BT, stasiun II pada koordinat 06² 43 '28.9” LS dan 110³3'22.5” BT, dan stasiun III pada koordinat 06³3'29.8” LS dan 110³3'23.3 BT.

\begin{tabular}{|c|c|c|c|c|c|}
\hline Stasiun & $\begin{array}{c}\text { Kerapatan } \\
\text { (Pohon/Ha) }\end{array}$ & $\begin{array}{l}\text { Diameter } \\
(\mathbf{c m})\end{array}$ & $\begin{array}{c}\text { Kriteria Baku } \\
\text { Kerapatan } \\
\text { Mangrove } \\
(\text { Pohon/Ha) } \\
\end{array}$ & $\begin{array}{c}\text { Komposisi Jenis } \\
\text { Mangrove }\end{array}$ & $\begin{array}{l}\text { Persentase } \\
\text { Jenis } \\
\text { Mangrove }\end{array}$ \\
\hline $\begin{array}{c}1 \\
\text { (padat) }\end{array}$ & 3200 & $10,5-24,3$ & $\begin{array}{l}>1.500 \\
\text { (padat) }\end{array}$ & $\begin{array}{l}\text { Avicennia marina } \\
\text { Rhizophora apiculata } \\
\text { Rhizophora mucronata }\end{array}$ & $\begin{array}{r}9,38 \% \\
56,24 \% \\
34,38 \%\end{array}$ \\
\hline $\begin{array}{c}2 \\
\text { (sedang) }\end{array}$ & 1500 & $11,1-30,5$ & $\begin{array}{l}\geq 1.000-1.500 \\
\quad(\text { sedang })\end{array}$ & $\begin{array}{l}\text { Avicennia marina } \\
\text { Rhizophora apiculata } \\
\text { Rhizophora mucronata }\end{array}$ & $\begin{array}{r}20 \% \\
33,3 \% \\
46,7 \%\end{array}$ \\
\hline $\begin{array}{c}3 \\
\text { (jarang) }\end{array}$ & 600 & $15,7-31,2$ & $\begin{array}{l}<1.000 \\
\text { (jarang) }\end{array}$ & $\begin{array}{l}\text { Avicennia marina } \\
\text { Rhizophora apiculata }\end{array}$ & $\begin{array}{l}16,7 \% \\
83,3 \%\end{array}$ \\
\hline
\end{tabular}

Tabel 1. Kerapatan Mangrove pada Lokasi Penelitian

\section{Kualitas air lokasi penelitian.}

Dapat dilihat dari data kualitas air yang diukur pada saat pelaksanaan sampling (tabel 2), terdapat perbedaan kedalaman dan konsentrasi oksigen pada tiap kerapatan. Kedalaman stasiun 3 (kerapatan mangrove jarang) paling dangkal diantara stasiun lainnya. Konsentrasi oksigen terlarut tertinggi terdapat pada stasiun 1 dengan kerapatan mangrove padat. Variabel lingkungan yang lain memiliki kisaran nilai yang tidak jauh berbeda. 
http://ejournal-s1.undip.ac.id/index.php/maquares

Tabel 2. Kualitas Air pada Tiga Kerapatan Mangrove

\begin{tabular}{lcccc}
\hline \multirow{2}{*}{ Variabel } & \multicolumn{3}{c}{ Kerapatan Mangrove } & Nilai Optimun \\
\cline { 2 - 4 } & Padat & Sedang & Jarang & - \\
\cline { 2 - 4 } Kedalaman $(\mathrm{cm})$ & $84-94$ & $94-104$ & $47-60$ & $23-32(\mathrm{KMNLH}, 2004)$ \\
Temperatur $\left({ }^{\circ} \mathrm{C}\right)$ & $29-32$ & $28-29$ & $30-31$ & $>0,05(\mathrm{KMNLH}, 2004)$ \\
Kecepatan arus $(\mathrm{m} / \mathrm{s})$ & $0,09-0,16$ & $0,15-0,17$ & $0,105-0,17$ & $20-40$ (Supriharyono,2000) \\
Salinitas $(\%$ o $)$ & $30-33$ & $30-33$ & $28-32$ & Lumpur $($ Walsh,1974 dalam \\
Substrat & Liat & Liat & Pasir & Halidah,2010) \\
pH & 8 & 8 & 8 & $7-8,5($ KMNLH,2004) \\
Oksigen terlarut $(\mathrm{mg} / \mathrm{l})$ & $3,4-4,0$ & $2,4-3,9$ & $2,6-3,2$ & $5,0-7,0$ (Effendi,2003) \\
\hline
\end{tabular}

Kelimpahan dan Komposisi Larva Ikan.

Selama penelitian kelimpahan larva ikan tertinggi diperoleh dari stasiun 1 (kerapatan mangrove padat) dengan nilai 290 individu/250 $\mathrm{m}^{3}$. Kelimpahan larva ikan pada stasiun 2 (kerapatan mangrove sedang) sebesar 133 individu $/ 250 \mathrm{~m}^{3}$. Sedangkan kelimpahan larva ikan terendah diperoleh dari stasiun 3 (kerapatan mangrove jarang) dengan nilai 79 individu $/ 250 \mathrm{~m}^{3}$. Selama penelitian diperoleh 502 individu yang terdiri dari 20 famili larva ikan. Famili Sparidae, Gobiidae, Nemipteridae, dan Lutjanidae merupakan famili yang mendominasi pada saat penelitian.

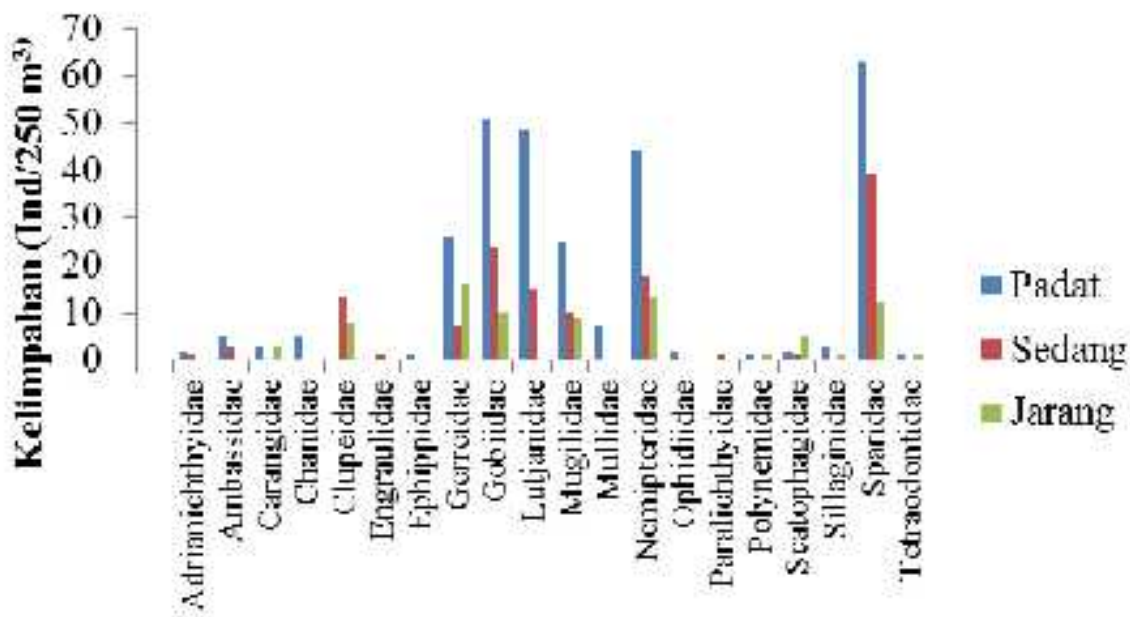

Famili Larva Ikan

Gambar 2. Kelimpahan Larva Ikan pada Tiga Kerapatan Mangrove

Hasil perhitungan mengenai kelimpahan larva ikan dari tiga kerapatan mangrove disajikan pada tabel 3.

Tabel 3. Kelimpahan Larva Ikan pada Tiga Kerapatan Mangrove

\begin{tabular}{llccc}
\hline \multirow{2}{*}{ No } & Pengambilan & \multicolumn{3}{c}{ Kerapatan Mangrove } \\
\cline { 3 - 5 } & sampel & Padat & Sedang & Jarang \\
\hline 1 & Sampling I & 106 & 47 & 21 \\
2 & Sampling II & 95 & 45 & 32 \\
3 & Sampling III & 89 & 41 & 26 \\
\hline \multicolumn{2}{l}{ Jumlah (ind/250 $\mathrm{m}^{3}$ ) } & 290 & 133 & 79 \\
\hline
\end{tabular}

Hubungan kelimpahan larva ikan pada tiga kerapatan mangrove.

Hubungan inii ditunjukkan pada gambar 2 yang menggambarkan kelimpahan larva ikan pada tiga kerapatan mangrove. 


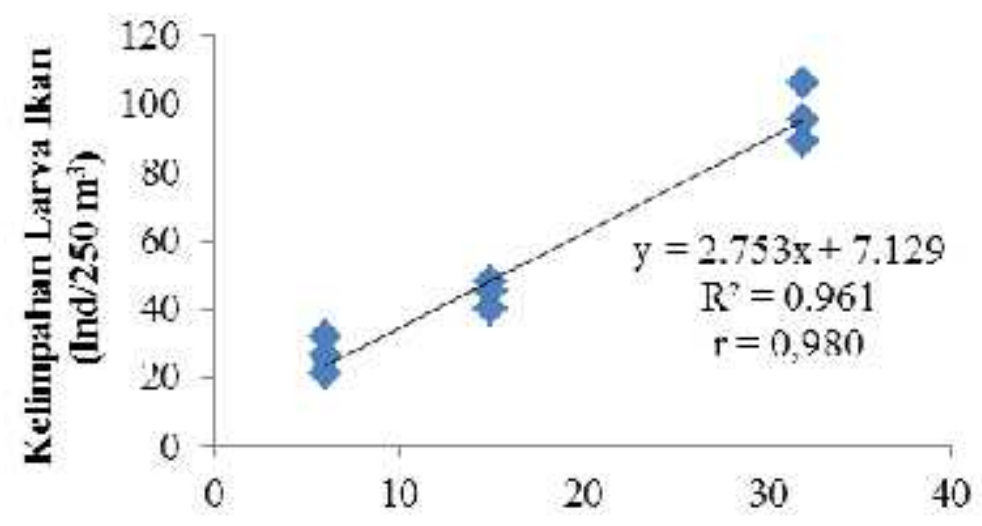

Kerapatan Mangrove (Pohon $/ \mathbf{1 0 0} \mathrm{m}^{2}$ )

Gambar 3. Grafik Hubungan Kelimapahan Larva Ikan dengan Tiga Kerapatan Mangrove

Pada hubungan kelimpahan larva ikan dengan tiga kerapatan mangrove menunjukkan persamaan $\mathrm{Y}=2,753 \mathrm{x}+7,129$ dengan signifikasi dimana $\mathrm{p}<0,05$. Nilai koefisien korelasi (r) adalah 0,980 dan koefisien determinasi $\left(\mathrm{R}^{2}\right)$ sebesar 0,961 .

\section{B. PEMBAHASAN}

\section{Karakteristik dan kerapatan mangrove.}

Hasil perhitungan kerapatan mangrove di lokasi penelitian yaitu, pada stasiun 1 dengan kerapatan mangrove padat terdapat 3200 pohon/Ha, stasiun 2 dengan kerapatan mangrove sedang terdapat $1500 \mathrm{Pohon} / \mathrm{Ha}$, sedangkan pada stasiun 3 dengan kerapatan mangrove jarang terdapat $\quad 600$ Pohon/Ha. Jenis-jenis mangrove yang dijumpai di kawasan ini adalah Rhizophora apiculata, Rhizophora mocrunata, dan Avicennia marina. Jenis mangrove yang mendominasi di kawasan ini adalah Rhizophora apiculata, jenis ini selalu ditemukan pada semua stasiun pengambilan sampel dengan kondisi yang baik. Hal ini diperkuat oleh pernyataan Field (1995) dalam Suryawan (2007) bahwa hutan mangrove pada umumnya mendominasi zona-zona pantai berlumpur dan delta estuaria pasang surut. Pada zona pasang surut yang luas mangrove membentuk hutan yang lebat, misalnya kawasan delta yang luas, lokasi penggenangan pasang surut, dan daerah yang merawa di muara sungai besar.

Menurut Romimohtarto dan Juwana (2005), membanjirnya air pasang mengenangi substrat dan mempersukar tumbuh-tumbuhan biasa untuk hidup di kawasan mangrove. Tetapi mangrove merah (Rhizophora spp.) mempunyai akar tunggang (prop root) untuk menunjang tegaknya pohon mangrove tersebut. Mangrove juga hidup di tanah yang miskin zat asam, sedangkan zat asam dari tanah diperlukan untuk respirasi akar. Sebagai penyesuaian hidup anaerobik, akar yang terkhususkan yang disebut akar nafas (pneumatophore) tumbuh di permukaan tanah.

\section{Kelimpahan larva ikan.}

Hasil proses analisa data kelimpahan larva ikan yang tertangkap di kawasan Delta Wulan dengan tiga kerapatan mangrove yang berbeda menunjukkan bahwa kelimpahan larva ikan tertinggi terdapat pada stasiun 1 (kerapatan mangrove padat) sebanyak 290 individu/ $250 \mathrm{~m}^{3}$. Kelimpahan larva ikan terendah terdapat pada stasiun 3 (kerapatan mangrove jarang) sebanyak 79 individu/250 $\mathrm{m}^{3}$. Diketahui bahwa kelimpahan larva ikan lebih banyak ditemukan di kawasan mangrove dengan kerapatan yang padat dibanding dengan kawasan mangrove dengan kerapatan sedang dan jarang. Hal tersebut tentu dipengaruhi keberadaan vegetasi mangrove yang memiliki fungsi ekologis sebagai daerah pemijahan (spawning ground), daerah asuhan (nursery ground), dan daerah mencari makan (feeding ground). Kawaroe et al. (2001) menyatakan bahwa kualitas ekosistem mangrove yang memiliki variasi kerapatan, produksi serasah, dan kelas genangan memperlihatkan mangrove sebagai tempat tumbuh dan mencari makan bagi beragam komunitas ikan. Selanjutnya Indriani et al. (2009) menyatakan bahwa kondisi struktur mangrove yang komplek menyebabkan ekosistem mangrove memiliki produktivitas tinggi dengan kaya akan bahan organik dan berupa detritus, sehingga berperan penting sebagai daerah asuhan bagi ikan komersil. Struktur fisik mangrove juga memberikan perlindungan bagi hewan nekton kecil terhadap predasi berupa naungan, yaitu dengan mengurangi visualisasi predator sehingga meningkatkan daya pertumbuhan dan kelangsungan hidup hewan nekton.

Sulistiyowati (2009) menyatakan bahwa keberadaan hutan mangrove di ekosistem sangat penting karena mereka memiliki potensi ekologis dan ekonomi. Hutan mangrove memiliki peran penting sebagai nursery area dan habitat dari berbagai macam ikan, udang, kerang-kerang, dan lain-lain. Di hutan ini pula banyak sumbersumber nutrien yang penting sebagai sumber makanan banyak spesies. Hutan mangrove juga berperan sebagai

\footnotetext{
${ }^{\circledR}$ Copyright by Management of Aquatic Resources (MAQUARES)
} 
green belt yang melindungi pantai dari erosi karena gelombang laut atau badai tsunami juga memerangkap sedimen sebagai aktivitas akresi.

Kelimpahan larva ikan pada stasiun 1 menghasilkan jumlah individu lebih banyak dibandingkan dengan stasiun 2 dan stasiun 3. Hal ini disebabkan oleh tingkat kerapatan mangrove dari stasiun 1 yaitu memiliki kerapatan yang padat. Kondisi tumbuhan mangrove pada stasiun 1 masih alami dan rapat yang berfungsi sebagai daerah pemijahan (nursery ground) serta penyedia pakan alami larva ikan yang ada di sana. Mangrove mempunyai peran penting bagi ekologi yang didasarkan atas produktivitas primernya dan produksi bahan organik yang berupa serasah, dimana bahan organik ini merupakan dasar rantai makanan. Serasah dari tumbuhan mangrove ini akan terdeposit pada dasar perairan dan terakumulasi terus-menerus dan akan menjadi sedimen yang kaya kandungan unsur hara, dan merupakan tempat yang baik untuk kelangsungan hidup fauna (McConnaughey dan Zottoli, 1983) dalam Cahyawan ,2011).

\section{Komposisi larva ikan.}

Komposisi larva ikan di lokasi ini memiliki keragaman yang tinggi. Gerreidae, Gobiidae, Mugilidae, Nemipteridae, Scatophagidae, dan Sparidae merupakan famili yang ditemukan di seluruh stasiun sampling, sedangkan famili lainnya ditemukan hanya pada stasiun tertentu. Famili yang mendominasi pada lokasi penelitian adalah Gobiidae, Lutjanidae, Nemipteridae, dan Sparidae. Selama penelitian larva yang tertangkap di Delta Wulan sebanyak 502 individu/250 $\mathrm{m}^{3}$ dari tiga kerapatan mangrove terdiri dari 20 famili yang didominasi oleh Sparidae (22,709\%), Gobiidae (16,932\%), Nemipteridae (14,940\%), dan Lutjanidae (12,749\%), sedangkan untuk jenis larva lainnya hanya ditemukan dalam jumlah sedikit.

Famili Sparidae ditemukan di semua stasiun pada saat sampling dan mendominasi di stasiun 1 dan 2, yang merupakan daerah mangrove dengan kerapatan padat dan jarang. Sparidae hanya ditemukan pada sampling ke-II dan ke-III. Jumlah Sparidae menurun pada sampling ke-III. Sparidae adalah keluarga dari ikan di ordo Perciformes yang ditemukan di perairan pantai beriklim subtropis dan tropis. Ikan ini adalah jenis ikan karnivora. Larva Sparidae hidup secara berkelompok (schooling), sedangkan ikan dewasa hidup soliter yang terjadi di perairan yang lebih dalam (FAO, 2001). Pernyataan ini memperkuat hasil komposisi larva ikan di lokasi penelitian yang menunjukkan bahwa Sparidae merupakan famili yang mendominasi di kawasan tersebut.

Seperti halnya Sparidae, Gobiidae ditemukan di semua stasiun pada saat sampling dan hanya ditemukan pada sampling ke-II dan ke-III. Gobiidae lebih banyak ditemukan di daerah mangrove dengan kerapatan padat $\left(51 \mathrm{ind} / 250 \mathrm{~m}^{3}\right)$ dan sedang $\left(24 \mathrm{ind} / 250 \mathrm{~m}^{3}\right)$ dibandingkan dengan daerah dengan kerapatan mangrove yang jarang $\left(10\right.$ ind $\left./ 250 \mathrm{~m}^{3}\right)$. Hal ini disebabkan kawasan mangrove merupakan sumber makanan dan sistem perakaran yang unik mampu memberikan perlindungan bagi larva, juvenil, maupun ikan dewasa (Subiyanto et al., 1995 dalam Subiyanto et al., 2008). Gobiidae ditemukan meningkat pada sampling ke-III. Selama penelitian, ditemukan banyak ikan Gelodok yang berasal dari famili Gobiidae di lokasi penelitian. Gobiidae memiliki dua sirip punggung. Gobiidae ditemukan melimpah di perairan laut dangkal dan estuaria. Kebanyakan dari jenis ini hidup dengan membuat lubang-lubang di dasar perairan (Leis and Carson-Ewart, 2000). Ikan-ikan ini senang melompat-lompat ke daratan, terutama di daerah berlumpur atau berair dangkal di sekitar hutan bakau ketika air surut. Menurut Janekarn dan Boonruang (1986) dalam Revika (2016), gobiidae umumnya ditemukan di perairan dangkal dengan substrat lumpur dan pasir serta daerah pantai. Hal ini sesuai dengan kondisi perairan di setiap stasiun pengambilan sampel.

Famili Nemipteridae ditemukan pada setiap sampling dan jumlahnya banyak ditemukan di daerah mangrove dengan kerapatan padat. Nemipteridae ditemukan di perairan pesisir pantai dengan substrat lumpur dan pasir serta perairan lepas pantai dengan berbagai kedalaman. Umumnya ikan jenis ini banyak ditemukan di perairan dangkal. FAO (2001), Nemipteridae dapat hidup secara soliter dan berkelompok (schooling). Ikan jenis ini merupakan ikan karnivora dengan makanan utamanya adalah ikan kecil lainnya, cumi-cumi, udang, dan polychaeta. Nemipteridae menunjukkan perbedaan ukuran yang berhubungan dengan rasio jenis kelamin yaitu individu betina lebih kecil dan individu jantan lebih besar. Musim pemijahan ikan jenis ini bervariasi dari masing-masing spesiesnya.

Famili Lutjanidae hanya ditemukan saat sampling ke-I. Berbeda dengan Sparidae dan Gobiidae, Lutjanidae hanya ditemukan di daerah mangrove dengan kerapatan padat dan sedang. Lutjanidae ditemukan pada sampling ke-I sebanyak 64 individu/250 $\mathrm{m}^{3}$. Hal ini dapat disebabkan oleh puncak musim pemijahan Lutjanidae yang terjadi sekitar bulan Maret-Mei dan September-November. Biasanya individu betina melakukan pemijahan beberapa kali dalam satu musim reproduksi. Lutjanidae memiliki umur panjang dan tingkat kematian alami yang rendah, tetapi cukup rentan terhadap overfishing (penangkapan yang berlebihan) (FAO, 2001). Contoh ikan dari famili Lutjanidae adalah ikan kakap. Lutjanidae adalah ikan karnivora yang ditemukan di berbagai habitat seperti mangrove, terumbu karang, substrat berpasir dan dalam, karang berbatu. Kebanyakan dari Lutjanidae adalah ikan demersal, tetapi empat dari lima subfamili yang ada merupakan ikan pelagis atau semi pelagis dan pemakan plankton. Banyak jenis dari Lutjanidae merupakan ikan ekonomis penting (Leis and Carson-Ewart, 2000). 


\section{Hubungan kelimpahan larva ikan dengan kerapatan mangrove yang berbeda.}

Antara kelimpahan larva ikan dengan perbedaan kerapatan mangrove ada hubungan yang nyata. Nilai korelasi antara kedua variabel r 0,980. Menurut Young (1982) dalam Sulaiman (2002) dengan pedoman kisaran korelasi 0,70 hingga 1,00 menunjukkan adanya hubungan yang tinggi. Korelasi antara kelimpahan larva ikan dengan kerapatan mangrove menunjukkan korelasi yang kuat. Nilai determinasi $\mathrm{R}^{2} 0,961$ menunjukkan bahwa 96,10\% kelimpahan larva ikan dapat dijelaskan oleh kerapatan mangrove, sedangkan sisanya $(3,90 \%)$ dapat ditentukan oleh variabel lain.

Perbedaan kelimpahan larva ikan pada setiap stasiun dapat dipengaruhi oleh variasi kerapatan mangrove yang berada di lokasi penelitian. Hal ini karena bahan organik hasil dekomposisi serasah hutan mangrove merupakan mata rantai ekologis utama yang menghubungkannya dengan perairan di sekitarnya. Banyaknya bahan organik menjadikan hutan mangrove sebagai tempat sumber makanan dan tempat asuhan berbagai biota seperti ikan, udang, kepiting. Produksi ikan dan udang di perairan laut sangat bergantung dengan produksi serasah yang dihasilkan oleh hutan mangrove (Coto et al., 1986 dalam Taqwa, 2010).

Berdasarkan hasil penelitian Khoiriya (1999) dalam Cahyawan (2011) disebutkan bahwa kelimpahan larva dan juvenil ikan yang paling tinggi dijumpai pada daerah dengan kerapatan mangrove yang tinggi pula, hal ini menunjukkan adanya hubungan yang positif antara kerapatan mangrove dengan jumlah individu larva ikan yang ada di daerah tersebut.

\section{KESIMPULAN}

Kesimpulan yang dapat diambil dari penelitian ini adalah sebagai berikut:

1. Kelimpahan larva ikan pada stasiun 1 (kerapatan mangrove padat) sebanyak 290 individu/250 $\mathrm{m}^{3}$, kelimpahan larva ikan pada stasiun 2 (kerapatan mangrove sedang) sebanyak 133 individu/250 $\mathrm{m}^{3}$, dan kelimpahan larva ikan pada stasiun 3 (kerapatan mangrove jarang) yaitu 79 individu $/ 250 \mathrm{~m}^{3}$.

2. Komposisi larva ikan pada stasiun 1 (kerapatan mangrove padat) terdiri atas famili Adrianichthyidae, Ambassidae, Carangidae, Chanidae, Ephippidae, Gerreidae, Gobiidae, Lutjanidae, Mugilidae, Mullidae, Nemipteridae, Ophidiidae, Polynemidae, Scatophagidae, Sillaginidae, Sparidae, dan Tetraodontidae. Komposisi larva ikan pada stasiun 2 (kerapatan mangrove sedang) terdiri atas famili Adrianichthyidae, Ambassidae, Clupeidae, Engraulidae, Gerreidae, Gobiidae, Lutjanidae, Mugilidae, Nemipteridae, Paralichthyidae, Scatophagidae, dan Sparidae. Komposisi larva ikan pada stasiun 3 (kerapatn mangrove jarang) terdiri atas famili Carangidae, Clupeidae, Gerreidae, Gobiidae, Mugilidae, Nemipteridae, Polynemidae, Scatophagidae, Sillaginidae, Sparidae, dan Tetraodontidae.

3. Nilai korelasi antara kelimpahan larva ikan dengan kerapatan mangrove yaitu sebesar $r=0,980$. Berdasarkan hal tersebut dapat disimpulkan bahwa terdapat hubungan yang positif antara kelimpahan larva ikan dengan kerapatan mangrove.

\section{UCAPAN TERIMA KASIH}

Penulis mengucapkan terima kasih kepada para penguji penelitian dan panitia ujian akhir program studi Manajemen Sumberdaya Perairan yaitu Prof.Dr.Ir. Djoko Suprapto, M.Sc, Dr.Ir. Bambang Sulardiono, M.Si, Churun Ain, S.Pi, M.Si dan Dr.Ir. Pujiono Wahyu Purnomo, M.S atas segala kritik dan saran yang diberikan dalam hasil penelitian ini serta semua pihak yang telah membantu dalam penyusunan skripsi ini.

\section{DAFTAR PUSTAKA}

Adi, W. 2007. Komposisi dan Kelimpahan Larva dan Juvenil Ikan yang Berasosiasi dengan Tingkat Kerapatan Lamun yang Berbeda di Pulau Panjang, Jepara. AKUATIK, 1(1): 7-11.

Cahyawan, Ari. 2011. Komposisi Jenis Larva Ikan di Perairan Pesisir Desa Bedono, Demak. [Skripsi]. Fakultas Perikanan dan Ilmu Kelautan, Universitas Diponegoro, Semarang, $54 \mathrm{hlm}$.

FAO. 2001. FAO Species Identification Guide for Fishery Purposes: The Living Marine Resources of The Western Central Pacific. Volume 3,4,5, dan 6. FAO, Rome.

Indriani, D.P., E.P. Sagala, dan A. Legasari. 2009. Keanekaragaman Jenis Ikan Terkait dengan Kondisi Kawasan Mangrove Hutan Nipah (Nypa fruticans Wurmb) di Perairan Sungai Cilik Kab. Banyuasin Sumatera Selatan. [Laporan Penelitian]. Universitas Sriwijaya.

Kawaroe, M. 2001. Kontribusi Ekosistem Mangrove Terhadap Struktur Komunitas Ikan di Pantai Utara Kabupaten Subang, Jawa Barat. Pesisir dan Lautan, 3(3): 12-25.

Kementerian Lingkungan Hidup. 2004. Keputusan Menteri Negara Lingkungan Hidup Nomor 201 Tahun 2004 tentang Baku Mutu Air Laut. Jakarta, Kementerian Lingkungan Hidup.

Leis, J.M. and B.M. Carson-Ewart. 2000. The Larvae of Indo-Pacific Coastal Fishes: An Identification Guide to Marine Fish Larvae. Fauna Malesiana; Vol.2. Leiden;Boston;Koln. Brill. 850 hlm.

Revika. 2016. Komposisi dan Kelimpahan Larva dan Juvenil Ikan di Sekitar Muara Sungai Tulung Demak. [Skripsi]. Fakultas Perikanan dan Ilmu Kelautan, Universitas Diponegoro, Semarang, 72 hlm.

\footnotetext{
${ }^{(C)}$ Copyright by Management of Aquatic Resources (MAQUARES)
} 
Romimohtarto, K. dan S. Juwana. 2005. Meroplankton Laut: Larva Hewan Laut yang Menjadi Plankton. Jakarta, Djambatan, $191 \mathrm{hlm}$.

Subiyanto, Ruswahyuni, dan D.G. Cahyono. 2008. Komposisi dan Distribusi Larva Ikan Pelagis di Estuaria Pelawang Timur, Segara Anakan, Cilacap. Saintek Perikanan, 4(1): 62-68.

Sudjana. 1996. Metode Statistika. Tarsito, Bandung, 235 hlm.

Sulaiman, W. 2002. Jalan Pintas Menguasai SPSS. Penerbit Andi, Yogyakarta. 170 hlm.

Sulistiyowati, H. 2009. Biodiversitas Mangrove di Cagar Alam Pulau Sempu. Saintek, 8(1): 59-63.

Suryawan, F. 2007. Keanekaragaman Vegetasi Mangrove Pasca Tsunami di Kawasan Pesisir Pantai Timur Nangroe Aceh Darussalam. Biodiversitas, 8(4): 262-265.

Suryono, C.A. 2006. Ekologi Perairan Delta Wulan Demak Jawa Tengah: Distribusi Kepiting (Infra Ordo Brachyura dan Anomura) di Kawasan Mangrove. Ilmu Kelautan, 11(4): 210-215.

Taqwa, A. 2010. Analisis Produktivitas Primer Fitoplankton dan Struktur Komunitas Fauna Makrobenthos Berdasarkan Kerapatan Mangrove di Kawasan Konservasi mangrove dan Bekantan Kota Tarakan, Kalimantan Timur. [Tesis]. Program Pascasarjana, Universitas Diponegoro, Semarang, 97 hlm. 